\title{
Brain Tumor Treatment: 2017 Update
}

\author{
Adri Chakraborty ${ }^{1}$, Jennifer $\mathrm{Han}^{2}$, Cristina Faltas ${ }^{3} \&$ Natalia Coleman ${ }^{4}$ \\ ${ }^{1}$ Medical Physiology, College of Medicine, Texas A\&M University, USA \\ ${ }^{2}$ Genitourinary Malignancies, Bristol-Myers Squibb, USA \\ ${ }^{3}$ Lab Technician, Igenomix Lab NY, USA \\ ${ }^{4}$ Biology Department, New Jersey City University, USA \\ Correspondence: Natalia Coleman, New Jersey City University, USA. E-mail: NColeman@njcu.edu
}

Received: November 21, 2017 Accepted: December 8, 2017 Online Published: January 28, 2018

doi:10.5539/cco.v7n1p30

URL: https://doi.org/10.5539/cco.v7n1p30

\begin{abstract}
Malignant brain tumors are a heterogeneous group of diseases arising from different cell types that affect both adults and children. The high recurrence rate of malignant brain tumors typically is due to reappearance of focal masses, indicating that a sub population of tumor cells are insensitive to current therapies and may be responsible for reinitiating tumor growth. It is generally agreed that the resistant tumor cells are comprised of cancer stem cells or tumor-initiating cells. While brain tumor stem cells (BTSCs) were first isolated within the last decade, much of the early research has been focused on identifying the BTSC markers and therapeutic targets. The challenge however, is to translate this knowledge to therapeutics. In the current review, we survey the remedial strategies to target BTSCs, which includes diagnostic, pharmacologic, immunologic, viral, and post-transcriptional approaches.
\end{abstract}

Keywords: cancer stem cells, brain neoplasms, glioma, therapeutics, cancer

\section{Introduction}

\subsection{Introduction to BTSC Therapeutics}

Malignant brain tumor is a leading cause of cancer-related death in children. In 2004, an estimated 7.2 per 100,000 people in the US developed malignant brain tumors, with a 5-year survival rate of only $28 \%$ (Porter, McCarthy et al. 2010). The location of brain tumors is within vital areas of the central nervous system, thus making it difficult for conventional therapeutic interventions including surgery and chemotherapy. The recurrence rate of brain tumor is high and typically manifests as focal masses, indicating that a sub population of tumor cells, able to escape current treatments, may be responsible for reinitiating tumor growth. Therefore, new targeted alternative therapies are vitally needed to treat brain tumor as the current therapeutic options are limited (Pardal, Clarke et al. 2003).

It is generally agreed that a high rate of recurrence in brain tumor is due to the resistance of a sub-population of cancer stem cells (CSCs) or tumor-initiating cells (Clarke, Dick et al. 2006). The involvement of CSCs in tumor formation was originally reported in malignant brain tumors within the last decade (Hemmati, Nakano et al. 2003, Singh, Clarke et al. 2003). Subsequently, brain tumor stem cells (BTSCs) have been reported to show resistance against radiation (Bao, Wu et al. 2006, Kang, Hur et al. 2008, Tomuleasa, Soritau et al. 2010) and numerous chemotherapeutic agents, including temozolomide and paclitaxel (Kong, Kim et al. 2008). BTSCs have also been associated with adult brain and pediatric brain tumors (Thirant, Bessette et al. 2011) expressing a shorter survival (Beier, Wischhusen et al. 2008) progressive phenotype (Kong, Kim et al. 2008), leading to a higher mortality rate (Pallini, Ricci-Vitiani et al. 2008, Laks, Masterman-Smith et al. 2009). Moreover, a retrospective analysis found that targeting the BTSC niche (distinct from the neural stem cell population) - with radiotherapy - led to a significantly decreased risk of the disease progression and dose-dependent improvement in patient survival (Evers, Lee et al. 2010). These recent studies suggest that BTSCs may have clinical relevance in malignant brain tumors.

Most of the research on BTSCs focuses upon the pursuit of relevant BTSC markers or therapeutic targets. However, these studies which identify the potential BTSC markers, do not focus upon them being a potential remedial target, which could hold more direct clinical promise. Therefore, in this review, we summarize the 
recent and ongoing therapeutic approaches and strategies to target BTSCs.

\subsection{Diagnostic Approach to Identify BTSCs}

The concept of the existence of BTSCs originally gained prominence when researchers started identifying cancer stem cells (CSCs) amongst human astrocytomas (glioma) (Altaner 2008), neuroblastoma (Walton, Kattan et al. 2004), meningioma (Hueng, Sytwu et al. 2011), schwannoma (Hodges, Karikari et al. 2011) and medulloblastoma (Lasky, Choe et al. 2009) sub-population. Characterizing BTSCs based on their source of origin or prognostic stages of growth is still a challenge as these tumor cells shared a similar marker attribute. Furthermore, identification of precursor or early stage detection markers of these cell populations becomes an extreme challenge. Table 1 illustrates some of the early precursor markers associated with different stages of cancer stem cell populations.

Recently, Beck and colleagues (Beck, Jin et al. 2011) used phage display to screen peptide libraries for ligands that preferentially bind to their targets in the gliomas (Pasqualini and Ruoslahti 1996). They identified a stem cell-targeting (GSCT) 'AQYLNPS' peptide that selectively binds to the N-terminal isotype(s) of nestin, an intermediate filament protein found exclusively in neural precursor cells (Lendahl, Zimmerman et al. 1990) and surprisingly expressed in undifferentiated glioblastoma BTSCs (Beck, Jin et al. 2011). Interestingly, the GSCT peptide effectively penetrated glioblastoma tissue to target nestin+ BTSCs in vitro (Beck, Jin et al. 2011). However, given the fact that nestin is not universally expressed in BTSCs, the GSCT peptide may only be targeting a subpopulation of BTSCs that express nestin. Nonetheless, these significant findings suggest that the GSCT peptide may have utility for therapeutic screening of BTSCs. Alternatively, CSCs were identified in a murine brain tumor population by expressing EGFP under the control of nucleostemin promoter (a p53 mediate cell cycle modulator often expressed by highly proliferative cells) (Tamase, Muraguchi et al. 2009). Furthermore, screening of BTSCs using flow-cytometry and Elisa have identified CD133, MMP-9, nestin, Pax6, Math-1, musashi-1, BMI-1, CXCR4, CX3CR1, c-Myc and Sox2 expressing BTSCs from both gliomas and medulloblastomas (Tamase, Muraguchi et al. 2009, Cox, Wilder et al. 2013, Sullivan, Nahed et al. 2014). 
Table 1. Characterization of Tumors based on markers

\begin{tabular}{|c|c|c|}
\hline Tumor Type & Cell markers & Specificity \\
\hline $\begin{array}{l}\text { Grade-IVAstrocytoma: } \\
\text { Glioblastoma (GBM) }\end{array}$ & $\begin{array}{l}\text { 1) Oct-4 } \\
\text { 2) CD-90(-ve)/VEGF } \\
\text { (+)/PGE2 (+) } \\
\text { 3)IL-17RA/CD } \\
\text { 133/SOX-2/Nestin } \\
\text { Eva1- (epithelial } \\
\text { V-like antigen 1) } \\
\text { CD133, CD15, CD49f }\end{array}$ & $\begin{array}{l}\text { 1) High expression acts as an independent prognosis marker for } \\
\text { malignant gliomas (Krogh Petersen, Jensen et al. 2016). } \\
\text { 2) Marker for Mesenchymal stromal cell in malignant gliomas } \\
\text { (Svensson, Ramos-Moreno et al. 2016). } \\
\text { 3) Markers for 2-19\% Glial stem cell precursors (Parajuli, } \\
\text { Anand et al. 2016) (Ohtsu, Nakatani et al. 2016). }\end{array}$ \\
\hline $\begin{array}{l}\text { Grade II-III } \\
\text { Low grade/ } \\
\text { Anaplastic } \\
\text { astrocytoma }\end{array}$ & $\begin{array}{l}\text { 1) Netrin-1 } \\
\text { 2) P2RY12 } \\
\text { 3) Testin } \\
\text { 4) B7-H6 }\end{array}$ & $\begin{array}{l}\text { 1) gain of stemness marker (Ylivinkka, Sihto et al. 2017). } \\
\text { 2) microglial astrocytoma marker (Zhu, Kros et al. 2017). } \\
\text { 3) prognostic marker (Steponaitis, Kazlauskas et al. 2016). } \\
\text { 4) latent grade III astrocytoma marker (Guo, Guo et al. 2016). }\end{array}$ \\
\hline Glioma & $\begin{array}{ll}\text { 1) } & \text { Nos-1 } \\
\text { 2) } & \text { CDA-1 }\end{array}$ & 1) Glioma stemcell maerker \\
\hline Schwannoma & $\begin{array}{ll}\text { 1) } & \text { PDGFR } \\
\text { 2) } & \text { Oct-4/ Nestin } \\
\text { 3) } & \text { Cytokeratin } \\
\text { 4) } & \text { Calretinin } \\
\text { 5) } & \text { CD56 } \\
\text { 6) } & \text { CD34 } \\
\text { 7) } & \text { S-100 } \\
\end{array}$ & $\begin{array}{l}\text { 1/2) Stem cell markers } \\
\text { 3) Retroperitonial Schwannoma marker } \\
\text { 4/5/6/7) Differentiation markers }\end{array}$ \\
\hline Neuroblastoma & $\begin{array}{ll}\text { 1) } & \text { LGR5 } \\
\text { 2) } & \text { CD133 } \\
\text { 3) } & \text { BMI1 } \\
\end{array}$ & $\begin{array}{l}\text { 1) Neuroblastoma proliferation } \\
\text { 2) Reduction of stemness of NB }\end{array}$ \\
\hline Meningioma & $\begin{array}{ll}\text { 1) } & \text { CD133 } \\
\text { 2) } & \text { ABCG mRNA } \\
\text { 3) Nestin } \\
\text { 4) } \\
\text { miR21 }\end{array}$ & $\begin{array}{l}\text { 1/2) stem cell marker } \\
\text { 3/4) Anaplastic meningioma }\end{array}$ \\
\hline Medulloblastoma & $\begin{array}{ll}\text { 1) } & \text { CD133 } \\
\text { 2) } & \text { SOX-2 } \\
\text { 3) } & \text { Mushashi1 } \\
\text { 4) } & \text { BMI1 } \\
\end{array}$ & 1) MB-stem cell markers \\
\hline
\end{tabular}

Note: Cell Markers: Surface, Specificity: Functionality

\section{Pharmacologic}

\subsection{Differentiation}

While the induction of differentiation of cancer cells is a rational therapeutic strategy for anticancer treatment, only a few agents, including retinoic acid, bone morphogenetic proteins (BMPs), and histone deacetylase (HDAC) inhibitors (Massard, Deutsch et al. 2006, Piccirillo, Reynolds et al. 2006) currently target cancer cell differentiation. All-trans retinoic acid (vitamin A) modulates cell differentiation and proliferation and is used as adjuvant therapy for acute promyelocytic leukemia(Massard, Deutsch et al. 2006). Treatment with retinoic acid induced differentiation of glioma BTSCs $e x$ vivo as well as growth-inhibiting, antimigratory, and anti-angiogenic effects in mice transplanted with undifferentiated glioma BTSCs (Campos, Wan et al. 2010).

BMPs are a known modulators of neural stem cells (Panchision and McKay 2002). Treatment with BMP4 has been shown to eliminate the tumorigenicity of transplanted glioma cells, and more importantly stops tumor growth and prevents death in mice bearing glioma transplants. BMPs have also been shown to induce formation of differentiated astrocytes from GBMs. However, enriched SOX transcription factor-binding motifs in these astrocytes raises questions about the differential commitment of the GBM cells and possible tumerogenic property of re-activation (Carén, Stricker et al.).

However, BMPs have been shown to reduce the BTSC subpopulation by activating their cognate receptors and triggering Smad protein signaling (Piccirillo, Reynolds et al. 2006). A second study has also shown that the 
neural precursor cells release BMP7, a paracrine tumor suppressor of glioma BTSCs that acts by activating Smad signaling (Chirasani, Sternjak et al. 2010). The observed effects of HDAC inhibitors in cancer treatment (Marks and Dokmanovic 2005) is mimicked by glioma neurospheres, which upon the treatment with HDAC inhibitors, induced differentiation in vitro through non-canonical Notch signaling and reduced the tumorigenicity of neurosphere xenografts in mice (Sun, Xia et al. 2009). However, a recent study has found that the treatment with HDAC inhibitors led to the accumulation of histone methylation. Combination treatment with HDAC and lysine-specific histone demethylase (LSD)-1 inhibitors resulted in synergistic apoptosis in glioblastoma cells but not normal astrocytes (Singh, Manton et al. 2011). Alternatively, drugs preventing L-MYC (Li, Oganesyan et al. 2016), HMGA-2 (Zhong, Liu et al. 2016), fatty acid synthase (FASN) (Yasumoto, Miyazaki et al. 2016), astrocyte elevated gene-1 (AEG-1) (Hu, Emdad et al. 2016), and lysine demethylase KDM1A (Sareddy, Viswanadhapalli et al. 2016) activity and promoting PAX6/DLX5 transcriptional activation of WNT signaling (Hu, Wang et al. 2016) prevented glioma stem cell morphology and induced astrocytic differentiation. These preclinical studies suggest that eliminating the glioblastoma stem cell (GBSc) population and inducing astrocytic differentiation of the glioma cells may be a viable selective treatment strategy to explore for BTSCs, although further testing is needed in an in vivo systems.

\subsection{Tumor Microenvironment}

The tumor microenvironment thrives under hypoxic conditions upon the up-regulation of hypoxia inducible factor: HIF-1 $\alpha$ and HIF-2 $\alpha$, which enhances the expression of stem-cell markers, chemo-resistance, and clonogenicity of BTSCs (McCord, Jamal et al. 2009, Bar, Lin et al. 2010, Pistollato, Abbadi et al. 2010, Pistollato, Rampazzo et al. 2010, Kolenda, Jensen et al. 2011). In contrast to the mitochondrial glucose oxidation phenotype of normal tissues(Kim, Tchernyshyov et al. 2006), HIF-1 $\alpha$ amplifies the expression of pyruvate dehydrogenase kinase (PDK), thereby contributing to the cytoplasmic glycolytic phenotype maintained in glioma. Dichloroacetate is an orphan small-molecule oral PDK inhibitor that has been shown to selectively improve mitochondrial function in cancer cells and decrease tumor growth and proliferation (Bonnet, Archer et al. 2007). Treatment with dichloroacetate improved mitochondrial function in freshly dissociated glioma tissue but not normal brain tissue. More importantly, administration of dichloroacetate for 15 months in 5 patients with glioblastoma resulted in some tumor regression and the patients demonstrated a good safety profile (Michelakis, Sutendra et al. 2010). These findings suggest that dichloroacetate may be an effective metabolic modulator for anticancer therapy and further clinical testing is warranted.

Accumulating evidence suggests that BTSCs, like normal stem cells, reside within vascular niches that help BTSCs to maintain their stem cell-like properties (Calabrese, Poppleton et al. 2007, Gilbertson and Rich 2007). Treatment with Interferon- $\beta$ in glioma xenografts disrupted these vascular niches by promoting perivascular cell growth forming a barrier between the glioma BTSCs and endothelial cells. This, indirectly reduced the tumor growth and the BTSC population (Williams, Sims et al. 2010). Although these results suggest that interferon- $\beta$ has anti-BTSC activity, the clinical use of interferon- $\beta$ may be limited by its known systemic toxicity and short half-life (Williams, Sims et al. 2010).

\subsection{Telomerase Antagonism}

A hallmark of cancer cells is the re-activation of telomerase, a riboprotein enzyme that counteracts the shortening of telomeres resulting from repeated DNA replication, which enables uncontrolled cell expansion (Shay and Wright 2002). In brain tumors, a correlation has been reported between telomerase activity and histologic grade (Falchetti, Larocca et al. 2002). Gliomas are often associated with mutations in the telomerase reverse transcriptase gene (TERT) promoter sites (Simon, Hosen et al. 2015). Previous studies have successfully used RNA interference to down-regulate the hTERT gene in the gliomas and LN18 cells (Wang, Xue et al. 2012, Lavanya, Sibin et al. 2016), inducing apoptotic cell death. Treatment of glioblastoma cells with the telomerase inhibitor imetelstat alone, or in combination with temozolomide and radiation, progressively shortened the length of telomeres, induces slowed cell proliferation and leads to eventual cell death (Marian, Cho et al. 2010, Barszczyk, Buczkowicz et al. 2014). More importantly, imetelstat treatment in mice bearing glioblastoma xenografts led to a significant inhibition of tumor growth, suggesting that telomerase antagonism may be a beneficial therapeutic strategy to explore in glioma (Marian, Cho et al. 2010). Another drug, MST-312 has been successfully shown to shorten telomerase end extension and induce cell cycle arrest in the brain tumor cells (Gurung, Lim et al. 2014).

\subsection{Apoptosis}

Arsenic trioxide $\left(\mathrm{As}_{2} \mathrm{O}_{3}\right)$ is an inorganic compound that has been used for centuries in various medicinal applications. While its mechanism of action is not well understood, it is thought that it acts via the induction of 
apoptosis (Emadi and Gore 2010). Recent studies reported that treatment with arsenic trioxide alone or with berberine or radiation reduces glioma cell growth and induces apoptosis or autophagy (Kim, Yoon et al. 2008, Lin, Kuo et al. 2008, Chiu, Ho et al. 2009). More recently, arsenic trioxide treatment has been shown to deplete the glioma BTSC subpopulation in vitro and in vivo by inducing apoptosis through the downregulation of Sox2 (Sun and Zhang 2011) and/or Notch1 and Hes1 (Zhen, Zhao et al. 2010). Furthermore, pretreatment with arsenic trioxide before ionizing radiation, temozolomide, and bevacizumab resulted in increased sensitivity to these treatments in glioblastoma multiforme BTSCs (Tomuleasa, Soritau et al. 2010). Arsenic trioxide also induces telomerase translocation from the nucleus of the cell to the cytoplasm, phosphorylates the telomeres and activates p53/p21 mediated apoptotic signaling pathways activation/ cell cycle arrests (Cheng, Li et al. 2016). These findings suggest that further study of arsenic trioxide in the treatment of brain tumors is warranted.

Furthermore, currently, the efficacy of drugs such as KIF20A inhibitor and pterostilbene are also being tested for potential glioma apoptotic inducers (Yu, Zhong et al. 2016, Saito, Ohta et al. 2017).

\subsection{Nuclear Hormone Receptors}

Nuclear hormone receptors are transcriptional factors known to regulate cell growth and differentiation. Constitutive androstane receptor (CAR) is an orphan nuclear hormone receptor that inhibits apoptosis and is critical for tumorigenesis (Qatanani and Moore 2005). Expression of CAR was found to be lower in BTSCs than in bulk glioma cells but increased in vitro by treatment with6-(4-chlorophenyl)imidazo[2,1-b][1,3]thiazole-5-carbaldehydeO-(3,4-dichlorobenzyl)oxime (CITCO), a selective CAR agonist (Chakraborty, Kanakasabai et al. 2011). CITCO dose-dependently inhibited CD133+ BTSC growth and expansion via cell cycle arrest and apoptosis in vitro and also inhibited BTSC tumorigenicity in mice bearing BTSC xenografts (Chakraborty, Kanakasabai et al. 2011). These effects were not observed in normal astrocytes (Chakraborty, Kanakasabai et al. 2011), suggesting that CITCO should be further explored as a selective targeted agent against BTSCs.

Alternatively, treatment of the gliomas with Estrogen receptor $\beta$ inhibitor: MF101, DPN and liquiritigenin and thyroid receptor inhibitor has been shown to induce decreased cell proliferation and prevent re-differentiation of the glioma cells (Alexandros, Iordanis et al. 2011, Sareddy, Nair et al. 2012).

\subsection{Autophagy}

Autophagy is a self-degradation process in which cytosomol components within a cell are removed via the lysosomal compartment. Although the goal of ionizing radiation is to induce apoptosis, irradiated glioma cells have been observed to undergo autophagy instead of apoptosis (Yao, Komata et al. 2003). Inactivation of the protein kinase mammalian target of rapamycin (mTOR) was found to induce autophagy in glioma cells (Takeuchi, Kondo et al. 2005). In a phase 1 trial, administration of the mTOR inhibitor rapamycin reduced tumor cell proliferation in association with mTOR inhibition in 7 of the 14 patients with PTEN-deficient recurrent glioblastoma (Cloughesy, Yoshimoto et al. 2008). Combined treatment with rapamycin and radiation increased autophagy in glioma BTSCs in vitro with subsequently decreased tumorigenicity in mice bearing BTSC transplants, and more importantly, limited tumor size and prolonged survival in xenografted mice with favorable safety (Zhuang, Li et al. 2011). mTOR inhibitors are currently in clinical testing for the treatment of glioma (U.S. National Institutes of Health , U.S. National Institutes of Health , U.S. National Institutes of Health , U.S. National Institutes of Health , Geoerger, Kieran et al. 2012, Yalon, Rood et al. 2012). Pretreatment with cilengitide, an orphan peptide inhibitor of integrins $\alpha \mathrm{v} \beta 3$ and $\alpha \mathrm{v} \beta 5$, increased autophagy and decreased cell self-renewal in glioma BTSCs and increased their sensitivity to $\gamma$-radiation, resulting in significantly shortened survival (Lomonaco, Finniss et al. 2011). A phase 2 study of cilengitide monotherapy showed modest efficacy in patients with recurrent glioblastoma (Gilbert, Kuhn et al. 2012). A pivotal phase 3 trial of cilengitide in combination with temozolomide and radiotherapy in patients with newly diagnosed glioblastoma is also currently being undertaken (U.S. National Institutes of Health).

\section{Treatment Optimization}

\subsection{Chemotherapy}

Although temozolomide is the standard chemotherapy for the treatment of glioma, drug resistance is common (Hegi, Diserens et al. 2005, Stupp, Mason et al. 2005). Topical findings have shown BTSCs interacting with astrocytes and up-regulate various survival genes, confering the BTSCs chemoresistant (Kim, Kim et al. 2011). A recent study found that glioma cells expressing CD133 were more resistant to temozolomide than unsorted glioma cells and showed enhanced transcriptional activity of the Notch and Sonic hedgehog pathways post-treatment in vitro (Ulasov, Nandi et al. 2011). Inhibition of Notch and Sonic signaling by co-administration 
of $\gamma$-secretase inhibitor-1 and cyclopamine with temozolomide resulted in significantly increased cell death in the CD133+ subpopulation in vitro, suggesting a potential additive benefit of combination therapy that should be further explored (Ulasov, Nandi et al. 2011).

The effect of temozolomide and other chemotherapeutic agents for BTSCs versus neural stem/progenitor cells (NSCs) was compared in a recent study (Gong, Schwartz et al. 2011). Temozolomide and cisplatin both demonstrated unfavorable cytotoxicity by being more effective at reducing the number of NSCs than BTSCs in vitro (Gong, Schwartz et al. 2011). In contrast, single-agent treatment with the newer chemotherapeutic agents bortezomib or erlotinib resulted in a greater reduction of BTSCs than NSCs (Gong, Schwartz et al. 2011). These findings emphasize the importance of drug selectivity in optimizing treatment regimens for patients.

Although 1,3-bis(2-chloroethyl)-1-nitrosourea (BCNU) is a commonly used chemotherapy for patients with glioblastoma multiforme, a small population of glioma cells containing BTSCs are resistant to BCNU (Kang and Kang 2007). These resistant glioma BTSCs have been reported to over-express a number of ion channel genes related to drug efflux (Kang and Kang 2007), especially chloride intracellular channel 1 (Kang and Kang 2008). Combined treatment with the chloride channel blocker 4,4'-diisothiocyanostilbene-2,2'-disulfonic acid (DIDS) and BCNU increased sensitivity to BCNU ex vivo and enhanced apoptosis in BCNU-resistant BTSCs in vitro (Kang and Kang 2008). These results suggest that blocking drug efflux mechanisms should be explored in in vivo models as a potential therapeutic strategy against BTSCs.

\subsection{Radiation}

The primary aim of radiation therapy is to induce G2/M cell cycle arrest and create radio-sensitivity of the BTSCs. Recent studies implemented Tomozolomide and radiation along with MMP14 knockout to prevent GBM proliferation by cell cycle inhibition and prevent angiogenesis (Ulasov, Thaci et al. 2013). Cyclooxygenase-2 (COX-2), another enzyme that converts arachidonic acid to prostaglandins are highly expressed in glioma cells (Joki, Heese et al. 2000) and CD133+ medulloblastoma cells than CD133- cells, suggesting that BTSCs may differentially express COX-2 (Chen, Hsu et al. 2010). Treatment with celecoxib, a widely used selective COX-2 inhibitor, effectively inhibited colony formation and cell proliferation in vitro and significantly increased radiosensitivity in mice bearing medulloblastoma xenotransplants (Chen, Hsu et al. 2010). Another study found high expression levels of COX-2 in CD133+ but not CD133- glioblastoma cells and similar antitumor and radiosensitization effects of celecoxib on $\mathrm{CD} 133+$ glioblastoma cells in vitro, as well as statistically significant decreases in tumor growth and increases in mean survival rate in mice bearing glioblastoma xenografts (Ma, Chiou et al. 2011). These studies suggest that adding celecoxib to radiotherapy for the treatment of brain tumors may warrant clinical study. Prevention of DNA strand break (DSB) repair post radiation treatment by targeted disruption of DSB repair protein activity in the gliomas can be also used to treat the disease. Some of the protein specifically targeted for such therapeutics are the disruption of RAD51 (King, Brend et al. 2017), DNA-dependent protein kinase catalytic subunit (DNA-PKcs), ataxia-telangiectasia mutated (ATM) (Gil del Alcazar, Hardebeck et al. 2014) and EGFRvIII (Mukherjee, McEllin et al. 2009) protein.

\section{Immunological Approaches for Targeting BTSCs}

The invasive nature of GBMs and MBs often localizes the tumor niche beyond the blood brain barrier along the inner pockets of brain parenchyma and mesenchyma beyond the reach of therapeutic agents (Cheng, Wu et al. 2011). This is also complimented by a decreased cellular and humoral immunity in vivo and the immunotherapies against glioma have not proven clinically efficacious (Parney, Hao et al. 2000). With recent advances in B-cell and dendritic cell vaccines, activating the body's innate immune response against treatment of gliomas remains a promising therapeutic strategy. An open-label study in 12 patients with glioblastoma multiforme, the most aggressive form of primary brain tumor, showed that single-agent treatment with a tumor B-cell vaccine of verified BTSC origin, achieved more favorable safety and longer-lasting survival benefit than mixed leukocyte culture (MLC) alone or in combination (Moviglia, Carrizo et al. 2008).

Dendritic cell vaccines are also some of the most promising immunotherapy strategies for glioma (Liau, Black et al. 2000, Liu, Khong et al. 2003, Liau, Prins et al. 2005, Liu, Akasaki et al. 2005). A dendritic cell vaccine prepared using BTSCs expressing CD133+, nestin+ tumor-associated antigens (EGFR, HER2, TRP2, MRP3, AIM2, SOX2, IL13R 2 ) (Xu, Liu et al. 2009) could induce a T-cell response and resulted in prolonged survival of rats bearing glioma BTSCs. A second dendritic cell vaccine prepared using sorted CD133+ tumor-associated antigens was shown to be significantly more cytotoxic in vitro than a dendritic cell vaccine prepared using unsorted tumor-associated antigens (Hua, Yao et al. 2011), suggesting that BTSCs are a promising antigen source for dendritic cell vaccinations. A phase 1 trial of dendritic cell vaccine loaded with BTSCs for progressive malignant brain tumor is ongoing (U.S. National Institutes of Health). 
Adoptive T-cell transfer is another immunotherapy strategy that involves ex vivo preparation of tumor-specific T-cells and subsequent transfer into subjects. Creation of D-270 MG and D-245 MG xenografts which mimics glioma phenotypes, are a promising approach towards creating an invasive tumor model (Bigner, Humphrey et al. 1990). Administration of HER2-specific T-cells, stimulated with HER2+ glioblastoma cells eliminated both CD133+ and CD133- HER2+ glioblastoma BTSCs in vitro (Ahmed, Salsman et al. 2010). Additionally, treatment with HER2-specific $\mathrm{T}$ cells led to measurable tumor response and prolonged survival in mice bearing glioblastoma xenografts (Ahmed, Salsman et al. 2010). Also mutated Epidermal growth factor receptor, (EGFRvIII) expressing invasive gliomas cells has been shown to be selectively targeted by T-cells expressing chimeric antigen receptors (CARs) (Miao, Choi et al. 2014). This treatment strategy warrants clinical exploration as a reproducible alternative to tumor cell or dendritic cell vaccines, which are limited by their inability to reproducibly produce tumor-specific T-cells (Fine 2004).

\section{Oncolytic Viral Approaches for Targeting BTSCs}

Oncolytic viruses preferentially infect cancer cells and can be used as a drug delivery system across the blood-brain barrier. Adenovirus 16p and chimpanzee adenovirus CV23 have been shown to infect both CD133+ and CD133- primary glioma cells (Skog, Edlund et al. 2007). Treatment with adenovirus Delta-24-Arg-Gly-Asp (RGD) (Jiang, Gomez-Manzano et al. 2007), the naturally occurring picornavirus Seneca Valley virus-001 (Yu, Baxter et al. 2011), or herpes simplex virus (HSV) vector G47 (Wakimoto, Kesari et al. 2009) effectively killed BTSCs and significantly improved survival in mice bearing BTSC xenografts. Combining HSV vector G47 $\Delta$ with temozolomide increased sensitivity to temozolomide in killing BTSCs while sparing neurons and induced long-term remission in 4 of 8 treated xenograft-bearing mice (Kanai, Rabkin et al. 2012). Lymphocytic choriomeningitis virus glycoprotein and vesicular stomatitis virus glycoprotein-pseudotyped lentiviral vectors were both able to efficiently infect glioblastoma BTSCs and carry the suicide gene HSV thymidine kinase fused to eGFP to mediate complete radiologic remission and significant survival benefit in rats bearing glioblastoma BTSC xenografts (Huszthy, Giroglou et al. 2009). These studies suggest the therapeutic potential of oncolytic viruses against BTSCs; indeed, Delta-24-RGD is currently in phase 1 clinical testing for the treatment of patients with recurrent glioma (U.S. National Institutes of Health). Myxoma virus (MYXV), in combination with rapamycin has been successfully shown to promote anti-tumor activity of BTSCs in mice infected with glioblastoma multiformeted and reduce CD133 expressing stem cells (Zemp, Lun et al. 2013).

\section{Post-translational}

MicroRNAs are a class of short noncoding RNAs that act as post-transcriptional regulators. MicroRNAs have been shown to promote, as well as inhibit BTSC manifestation (Teplyuk, Mollenhauer et al. 2012, Lee, Finniss et al. 2013, Tominaga, Kosaka et al. 2015). BTSCs have been shown to induce microRNAs (miR-181c) to evade the blood brain barrier by modulating their actin dynamics and initiate migration (Tominaga, Kosaka et al. 2015). Meanwhile, transfection of miR-124 or microR-137 promoted differentiation in CD133+ glioblastoma multiforme BTSCs and reduced glioblastoma multiforme cell proliferation in vitro (Silber, Lim et al. 2008). miR-124 induced down regulation of Nur77 has been shown to reduce glioma cell viability, proliferation and invasiveness (Tenga, Beard et al. 2016). miR-326 transfection has been shown to be cytotoxic to both normal glioma cells and glioma BTSCs, thus, inhibiting glioma tumorigenicity in mice bearing xenografts (Kefas, Comeau et al. 2009). Expression of miR-34a has been shown to initiate glioma BTSC differentiation and reduce glioma xenograft growth (Guessous, Zhang et al. 2010). Similarly, miR-130b has been shown as a prognostic marker for glioma cell migration and invasiveness (Sheng, Chen et al. 2015). miR-497 upregulation by glioma cells confers resistance to the cells to the temozolomide treatment ( $\mathrm{Zhu}, \mathrm{Tu}$ et al. 2017). Lastly, miR-9 was found to inhibit mesenchymal differentiation in glioma BTSCs (Kim, Huang et al. 2011). Together these findings suggest that microRNAs may play multiple regulatory roles for BTSCs and warrant further exploration. Recent studies focus on microRNA profiling of cerebrospinal fluid of patients with GBM. qRT-PCR data makes an effort to classify metastasis and remission stages of GBM by profiling miR-10b, miR-21, miR-141, miR-200a, miR-200b, miR-200c,miR-15b and miR-125b as potential biomarkers of BTSCs (Teplyuk, Mollenhauer et al. 2012).

\section{Conclusion}

The field of BTSC research has grown exponentially in the past decade. Much of the initial research was focused on isolating BTSCs in different types of brain tumors or on adding to our understanding of BTSC biology. These early foundational studies have enabled a number of more recent studies to shift their focus toward translational medicine. The specific therapeutic strategies summarized in this review suggest myriad possible modalities for targeting BTSCs. Some strategies aim to block the maintenance of stem-cell-like properties of BTSCs by 
inducing differentiation or disrupting the CSC niche, while other strategies follow the traditional approach of inducing cell death via apoptosis, autophagy or radiochemotherapy. Provoking a tumor-specific immune response using tumor-associated antigens remains a promising therapeutic strategy for targeting both bulk tumor cells and BTSCs. Lastly, the relatively recent discoveries that oncolytic viruses and microRNAs may prove useful as targeted agents or as delivery systems for other targeted agents against BTSCs is encouraging. While these findings are at early research stages, the challenge is to translate these approaches to clinical developments.

It has been shown that serum-derived cell lines of malignant brain tumors are poor genotypic and phenotypic representatives of human brain tumors (Lee, Kotliarova et al. 2006). Accordingly, studies conducted using BTSCs derived from established cancer cell lines should be repeated using freshly dissociated tumor samples, freshly derived tumor cell lines grown in serum-free culture, or in vivo rodent models to confirm their findings. Another major challenge to the proposed therapeutic strategies is the requirement that they should selectively target BTSCs while sparing neural stem or progenitor cells. Considering the ongoing challenge faced by traditional cytotoxic agents to target cancer cells while sparing normal tissue cells, this requirement may be equally challenging with the BTSCs. Moreover, recent reports have questioned the value of the most frequently cited potential BTSC marker, CD133, given the findings of CD133- BTSC populations (Beier, Hau et al. 2007, Joo, Kim et al. 2008, Ogden, Waziri et al. 2008, Yao, Wang et al. 2008, Clement, Dutoit et al. 2009, Chen, Nishimura et al. 2010, Schittenhelm, Simon et al. 2011) and variable CD133 expression depending on tumor grade (Rebetz, Tian et al. 2008), environmental conditions (i.e., hypoxia and mitochondrial dysfunction) (Griguer, Oliva et al. 2008), location (i.e., single BTSC versus BTSCs residing in niches) (Christensen, Schroder et al. 2011), and experimental assay techniques (Hermansen, Christensen et al. 2011). Whether this variability of expression extends to other putative BTSC markers will determine the clinical utility of therapeutic strategies targeting single BTSC markers, such as the aforementioned GCST peptide that selectively recognizes nestin+ BTSCs. Finally, while a few of the aforementioned targeted agents are currently in clinical testing, ultimately only the demonstration of safety and efficacy in pivotal clinical trials will provide definitive evidence of the translational relevance of these agents and help to inform the future direction of therapeutic strategies.

\section{Acknowledgments}

We gratefully acknowledge Dr. Arie Abo (CIRM) for helpful discussions and critical reading of the manuscript.

\section{References}

Ahmed, N., Salsman, V. S., Kew, Y., Shaffer, D., Powell, S., Zhang, Y. J., Grossman, R. G., Heslop, H. E., \& Gottschalk, S. (2010). HER2-specific T cells target primary glioblastoma stem cells and induce regression of autologous experimental tumors. Clin Cancer Res., 16(2), 474-485. https://doi.org/10.1158/1078-0432.CCR-09-1322

Alexandros, L., Iordanis, M., Athanasios, Z., Konstantinos, E., Robert-William, L., \& Constantinos, P. (2011). Cell-Type-Dependent Thyroid Hormone Effects on Glioma Tumor Cell Lines. Journal of Thyroid Research, 8. https://doi.org/10.4061/2011/856050

Altaner, C. (2008). Glioblastoma and stem cells. Neoplasma, 55(5), 369-374.

Bao, S., Wu, Q., McLendon, R. E., Hao, Y., Shi, Q., Hjelmeland, A. B., Dewhirst, M. W., Bigner, D. D., \& Rich, J. N. (2006). Glioma stem cells promote radioresistance by preferential activation of the DNA damage response. Nature, 444(7120), 756-760. https://doi.org/10.1038/nature05236

Bar, E. E., A. Lin, V. Mahairaki, W. Matsui \& Eberhart, C. G. (2010). Hypoxia increases the expression of stem-cell markers and promotes clonogenicity in glioblastoma neurospheres. Am J Pathol, 177(3), 1491-1502. https://doi.org/10.2353/ajpath.2010.091021

Barszczyk, M., Buczkowicz, P., Castelo-Branco, P., Mack, S. C., Ramaswamy, V., Mangerel, J., ... Hawkins, C. (2014). Telomerase inhibition abolishes the tumorigenicity of pediatric ependymoma tumor-initiating cells. Acta Neuropathol, 128(6), 863-877. https://doi.org/10.1007/s00401-014-1327-6

Beck, S., Jin, X., Yin, J., Kim, S. H., Lee, N. K., Oh, S. Y., ... Choi, Y. J. (2011). Identification of a peptide that interacts with Nestin protein expressed in brain cancer stem cells. Biomaterials, 32(33), 8518-8528. https://doi.org/10.1016/j.biomaterials.2011.07.048

Beier, D., Hau, P., Proescholdt, M., Lohmeier, A., Wischhusen, J., Oefner, P. J., ... Beier, C. P. (2007). CD133(+) and CD133(-) glioblastoma-derived cancer stem cells show differential growth characteristics and molecular profiles. Cancer Res., 67(9), 4010-4015. https://doi.org/10.1158/0008-5472.CAN-06-4180 
Beier, D., Wischhusen, J., Dietmaier, W., Hau, P., Proescholdt, M., Brawanski, ... Beier, C. P. (2008). CD133 expression and cancer stem cells predict prognosis in high-grade oligodendroglial tumors. Brain Pathol, 18(3), 370-377. https://doi.org/10.1111/j.1750-3639.2008.00130.x

Bigner, S. H., Humphrey, P. A., Wong, A. J., Vogelstein, B., Mark, J., Friedman, H. S., \& Bigner, D. D. (1990). Characterization of the epidermal growth factor receptor in human glioma cell lines and xenografts. Cancer Res, 50(24), 8017-8022.

Bonnet, S., Archer, S. L., Allalunis-Turner, J., Haromy, A., Beaulieu, C., Thompson, R., ... Michelakis, E. D. (2007). A mitochondria-K+ channel axis is suppressed in cancer and its normalization promotes apoptosis and inhibits cancer growth. Cancer Cell, 11(1), 37-51. https://doi.org/10.1016/j.ccr.2006.10.020

Calabrese, C., Poppleton, H., Kocak, M., Hogg, T. L., Fuller, C., Hamner, B., ... Gilbertson, R. J. (2007). A perivascular niche for brain tumor stem cells. Cancer Cell, 11(1), 69-82. https://doi.org/10.1016/j.ccr.2006.11.020

Campos, B., Wan, F., Farhadi, M., Ernst, A., Zeppernick, F., Tagscherer, K. E., ... Herold-Mende, C. (2010). Differentiation therapy exerts antitumor effects on stem-like glioma cells. Clin Cancer Res., 16(10), 2715-2728. https://doi.org/10.1158/1078-0432.CCR-09-1800

Carén, H., Stefan, H. Stricker, Bulstrode, H., Gagrica, S., Johnstone, E., Thomas, E., ... Steven, M. Pollard. (2015). Glioblastoma Stem Cells Respond to Differentiation Cues but Fail to Undergo Commitment and Terminal Cell-Cycle Arrest. Stem Cell Reports, 5(5), 829-842. https://doi.org/10.1016/j.stemcr.2015.09.014

Chakraborty, S., Kanakasabai, S., \& Bright, J. J. (2011). Constitutive androstane receptor agonist CITCO inhibits growth and expansion of brain tumour stem cells. Br J Cancer, 104(3), 448-459. https://doi.org/10.1038/sj.bjc.6606064

Chen, K. H., Hsu, C. C., Song, W. S., Huang, C. S., Tsai, C. C., Kuo, C. D., ... Chen, Y. W. (2010). Celecoxib enhances radiosensitivity in medulloblastoma-derived CD133-positive cells. Childs Nerv Syst, 26(11), 1605-1612. https://doi.org/10.1007/s00381-010-1190-2

Chen, R., Nishimura, M. C., Bumbaca, S. M., Kharbanda, S., Forrest, W. F., Kasman, I. M., ... Phillips, H. S. (2010). A hierarchy of self-renewing tumor-initiating cell types in glioblastoma. Cancer Cell, 17(4), 362-375. https://doi.org/10.1016/j.ccr.2009.12.049

Cheng, L., Wu, Q., Guryanova, O. A., Huang, Z., Huang, Q., Rich, J. N., \& Bao, S. (2011). Elevated Invasive Potential of Glioblastoma Stem Cells. Biochemical and biophysical research communications, 406(4), 643-648. https://doi.org/10.1016/j.bbrc.2011.02.123

Cheng, Y., Li, Y., Ma, C., Song, Y., Xu, H., Yu, H., ... Zhao, G. (2016). Arsenic trioxide inhibits glioma cell growth through induction of telomerase displacement and telomere dysfunction. Oncotarget, 7(11), 12682-12692. https://doi.org/10.18632/oncotarget.7259

Chirasani, S. R., Sternjak, A., Wend, P., Momma, S., Campos, B., Herrmann, I. M., ... Glass, R. (2010). Bone morphogenetic protein-7 release from endogenous neural precursor cells suppresses the tumourigenicity of stem-like glioblastoma cells. Brain, 133(Pt 7), 1961-1972. https://doi.org/10.1093/brain/awq128

Chiu, H. W., Ho, S. Y., Guo, H. R., \& Wang, Y. J. (2009). Combination treatment with arsenic trioxide and irradiation enhances autophagic effects in U118-MG cells through increased mitotic arrest and regulation of PI3K/Akt and ERK1/2 signaling pathways. Autophagy, 5(4), 472-483 https://doi.org/7759

Christensen, K., Schroder, H. D., \& Kristensen, B. W. (2011). CD133+ niches and single cells in glioblastoma have different phenotypes. J Neurooncol, 104(1), 129-143. https://doi.org/10.1007/s11060-010-0488-y

Clarke, M. F., Dick, J. E., Dirks, P. B., Eaves, C. J., Jamieson, C. H., Jones, D. L., ... Wahl, G. M. (2006). Cancer stem cells--perspectives on current status and future directions: AACR Workshop on cancer stem cells. Cancer Res, 66(19), 9339-9344. https://doi.org/10.1158/0008-5472.CAN-06-3126

Clement, V., Dutoit, V., Marino, D., Dietrich, P. Y., \& Radovanovic, I. (2009). Limits of CD133 as a marker of glioma self-renewing cells. Int J Cancer, 125(1), 244-248. https://doi.org/10.1002/ijc.24352

Cloughesy, T. F., Yoshimoto, K., Nghiemphu, P., Brown, K., Dang, J., Zhu, S., ... Sawyers, C. L. (2008). Antitumor activity of rapamycin in a Phase I trial for patients with recurrent PTEN-deficient glioblastoma. PLoS Med., 5(1), e8. https://doi.org/10.1371/journal.pmed.0050008

Cox, J. L., Wilder, P. J., Gilmore, J. M., Wuebben, E. L., Washburn, M. P., \& Rizzino, A. (2013). The SOX2-Interactome in Brain Cancer Cells Identifies the Requirement of MSI2 and USP9X for the Growth of 
Brain Tumor Cells. PLoS ONE, 8(5), e62857. https://doi.org/10.1371/journal.pone.0062857

Emadi, A., \& Gore, S. D. (2010). Arsenic trioxide - An old drug rediscovered. Blood Rev., 24(4-5), 191-199 https://doi.org/10.1016/j.blre.2010.04.001

Evers, P., Lee, P. P., DeMarco, J., Agazaryan, N., Sayre, J. W., Selch, M., \& Pajonk, F. (2010). Irradiation of the potential cancer stem cell niches in the adult brain improves progression-free survival of patients with malignant glioma. BMC Cancer, 10, 384. https://doi.org/10.1186/1471-2407-10-384

Falchetti, M. L., Larocca, L. M., \& Pallini, R. (2002). Telomerase in brain tumors. Childs Nerv Syst, 18(3-4), 112-117. https://doi.org/10.1007/s00381-002-0562-7

Fine, H. A. (2004). Toward a glioblastoma vaccine: promise and potential pitfalls. J Clin Oncol, 22(21), 4240-4243. https://doi.org/10.1200/JCO.2004.06.927

Geoerger, B., Kieran, M. W., Grupp, S., Perek, D., Clancy, J., Krygowski, M., ... Spunt, S. L. (2012). Phase II trial of temsirolimus in children with high-grade glioma, neuroblastoma and rhabdomyosarcoma. Eur $J$ Cancer, 48(2), 253-262. https://doi.org/10.1016/j.ejca.2011.09.021

Gil del Alcazar, C. R., Hardebeck, M. C., Mukherjee, B., Tomimatsu, N., Gao, X., Yan, J., ... Burma, S. (2014). Inhibition of DNA double-strand break repair by the dual PI3K/mTOR inhibitor NVP-BEZ235 as a strategy for radiosensitization of glioblastoma. Clin Cancer Res., 20(5), 1235-1248. https://doi.org/10.1158/1078-0432.ccr-13-1607

Gilbert, M. R., Kuhn, J., Lamborn, K. R., Lieberman, F., Wen, P. Y., Mehta, M., ... Prados, M. (2012). Cilengitide in patients with recurrent glioblastoma: the results of NABTC 03-02, a phase II trial with measures of treatment delivery. J Neurooncol, 106(1), 147-153. https://doi.org/10.1007/s11060-011-0650-1

Gilbertson, R. J., \& Rich, J. N. (2007). Making a tumour's bed: glioblastoma stem cells and the vascular niche. Nat Rev Cancer, 7(10), 733-736. https://doi.org/10.1038/nrc2246

Gong, X., Schwartz, P. H., Linskey, M. E., \& Bota, D. A. (2011). Neural stem/progenitors and glioma stem-like cells have differential sensitivity to chemotherapy. Neurology, 76(13), 1126-1134. https://doi.org/10.1212/WNL.0b013e318212a89f

Griguer, C. E., Oliva, C. R., Gobin, E., Marcorelles, P., Benos, D. J., Lancaster, J. R., \& Gillespie, G. Y. (2008). CD133 is a marker of bioenergetic stress in human glioma. PLoS One, 3(11), e3655. https://doi.org/10.1371/journal.pone.0003655

Guessous, F., Zhang, Y., Kofman, A., Catania, A., Li, Y., Schiff, D., ... Abounader, R. (2010). microRNA-34a is tumor suppressive in brain tumors and glioma stem cells. Cell Cycle, 9(6), 1031-1036 https://doi.org/10987

Guo, J. G., Guo, C. C., He, Z. Q., Liu, Z. G., Wang, Y., \& Mou, Y. G. (2016). Clinical significance of B7-H6 protein expression in astrocytoma. Onco Targets Ther, 9, 3291-3297. https://doi.org/10.2147/ott.s103771

Gurung, R. L., Lim, H. K., Venkatesan, S., Lee, P. S. W., \& Hande, M. P. (2014). Targeting DNA-PKcs and telomerase in brain tumour cells. Molecular Cancer, 13, 232. https://doi.org/10.1186/1476-4598-13-232

Hegi, M. E., Diserens, A. C., Gorlia, T., Hamou, M. F., de Tribolet, N., Weller, M., ... Stupp, R. (2005). MGMT gene silencing and benefit from temozolomide in glioblastoma. $N$ Engl J Med., 352(10), 997-1003. https://doi.org/10.1056/NEJMoa043331

Hemmati, H. D., Nakano, I., Lazareff, J. A., Masterman-Smith, M., Geschwind, D. H., Bronner-Fraser, M., \& Kornblum, H. I. (2003). Cancerous stem cells can arise from pediatric brain tumors. Proc Natl Acad Sci USA, 100(25), 15178-15183. https://doi.org/10.1073/pnas.2036535100

Hermansen, S. K., Christensen, K. G., Jensen, S. S., \& Kristensen, B. W. (2011). Inconsistent immunohistochemical expression patterns of four different CD133 antibody clones in glioblastoma. $J$ Histochem Cytochem, 59(4), 391-407. https://doi.org/10.1369/0022155411400867

Hodges, T. R., Karikari, I. O., Nimjee, S. M., Tibaleka, J., Cummings, T. J., Radhakrishnan, S., \& Friedman, A. H. (2011). Fourth Ventricular Schwannoma: Identical Clinicopathologic Features as Schwann Cell-Derived Schwannoma with Unique Etiopathologic Origins. Case Reports in Medicine, 2011, 165954. https://doi.org/10.1155/2011/165954

Hu, B., Emdad, L., Kegelman, T. P., Shen, X. N., Das, S. K., Sarkar, D., \& Fisher, P. B. (2016). Astrocyte Elevated Gene-1 Regulates Beta-catenin Signaling to Maintain Glioma Stem-like Stemness and Self-renewal. Mol Cancer Res. https://doi.org/10.1158/1541-7786.mcr-16-0239 
Hu, B., Wang, Q., Wang, Y. A., Hua, S., Sauve, C. G., Ong, D., ... DePinho, R. A. (2016). Epigenetic Activation of WNT5A Drives Glioblastoma Stem Cell Differentiation and Invasive Growth. Cell, 167(5), 1281-1295.e1218. https://doi.org/10.1016/j.cell.2016.10.039

Hua, W., Yao, Y., Chu, Y., Zhong, P., Sheng, X., Xiao, B., ... Zhou, L. (2011). The CD133+ tumor stem-like cell-associated antigen may elicit highly intense immune responses against human malignant glioma. $J$ Neurooncol, 105(2), 149-157. https://doi.org/10.1007/s11060-011-0572-y

Hueng, D. Y., Sytwu, H. K., Huang, S. M., Chang, C., \& Ma, H. I. (2011). Isolation and characterization of tumor stem-like cells from human meningiomas. J Neurooncol 104(1), 45-53. https://doi.org/10.1007/s11060-010-0469-1

Huszthy, P. C., Giroglou, T., Tsinkalovsky, O., Euskirchen, P., Skaftnesmo, K. O., Bjerkvig, R., von Laer, D., \& Miletic, H. (2009). Remission of invasive, cancer stem-like glioblastoma xenografts using lentiviral vector-mediated suicide gene therapy. PLoS One, 4(7), e6314. https://doi.org/10.1371/journal.pone.0006314

Jiang, H., Gomez-Manzano, C., Aoki, H., Alonso, M. M., Kondo, S., McCormick, F., ... Fueyo, J. (2007). Examination of the therapeutic potential of Delta-24-RGD in brain tumor stem cells: role of autophagic cell death. J Natl Cancer Inst, 99(18), 1410-1414. https://doi.org/10.1093/jnci/djm102

Joki, T., Heese, O., Nikas, D. C., Bello, L., Zhang, J., Kraeft, S. K., ... Black, P. M. (2000). Expression of cyclooxygenase 2 (COX-2) in human glioma and in vitro inhibition by a specific COX-2 inhibitor, NS-398. Cancer Res., 60(17), 4926-4931.

Joo, K. M., Kim, S. Y., Jin, X., Song, S. Y., Kong, D. S., Lee, J. I., ... Nam, D. H. (2008). Clinical and biological implications of CD133-positive and CD133-negative cells in glioblastomas. Lab Invest, 88(8), 808-815. https://doi.org/10.1038/labinvest.2008.57

Kanai, R., Rabkin, S. D., Yip, S., Sgubin, D., Zaupa, C. M., Hirose, Y., ... Martuza, R. L. (2012). Oncolytic virus-mediated manipulation of DNA damage responses: synergy with chemotherapy in killing glioblastoma stem cells. J Natl Cancer Inst., 104(1), 42-55. https://doi.org/10.1093/jnci/djr509

Kang, M. K., Hur, B. I., Ko, M. H., Kim, C. H., Cha, S. H., \& Kang, S. K. (2008). Potential identity of multi-potential cancer stem-like subpopulation after radiation of cultured brain glioma. BMC Neurosci, 9, 15. https://doi.org/10.1186/1471-2202-9-15

Kang, M. K., \& Kang, S. K. (2007). Tumorigenesis of chemotherapeutic drug-resistant cancer stem-like cells in brain glioma. Stem Cells Dev., 16(5), 837-847. https://doi.org/10.1089/scd.2007.0006

Kang, M. K., \& Kang, S. K. (2008). Pharmacologic blockade of chloride channel synergistically enhances apoptosis of chemotherapeutic drug-resistant cancer stem cells. Biochem Biophys Res Commun, 373(4), 539-544. https://doi.org/10.1016/j.bbrc.2008.06.070

Kefas, B., Comeau, L., Floyd, D. H., Seleverstov, O., Godlewski, J., Schmittgen, T., ... Purow, B. (2009). The neuronal microRNA miR-326 acts in a feedback loop with notch and has therapeutic potential against brain tumors. J Neurosci, 29(48), 15161-15168. https://doi.org/10.1523/JNEUROSCI.4966-09.2009

Kim, E. H., Yoon, M. J., Kim, S. U., Kwon, T. K., Sohn, S., \& Choi, K. S. (2008). Arsenic trioxide sensitizes human glioma cells, but not normal astrocytes, to TRAIL-induced apoptosis via CCAAT/enhancer-binding protein homologous protein-dependent DR5 up-regulation. Cancer Res., 68(1), 266-275. https://doi.org/10.1158/0008-5472.CAN-07-2444

Kim, J. W., Tchernyshyov, I., Semenza, G. L., \& Dang, C. V. (2006). HIF-1-mediated expression of pyruvate dehydrogenase kinase: a metabolic switch required for cellular adaptation to hypoxia. Cell Metab, 3(3), 177-185. https://doi.org/10.1016/j.cmet.2006.02.002

Kim, S.-J., Kim, J.-S., Park, E. S., Lee, J.-S., Lin, Q., Langley, R. R., ... Fidler, I. J. (2011). Astrocytes Upregulate Survival Genes in Tumor Cells and Induce Protection from Chemotherapy. Neoplasia (New York, N.Y.), 13(3), 286-298. https://doi.org/10.1593/neo.11112

Kim, T. M., Huang, W., Park, R., Park, P. J., \& Johnson, M. D. (2011). A developmental taxonomy of glioblastoma defined and maintained by MicroRNAs. Cancer Res., 71(9), 3387-3399. https://doi.org/10.1158/0008-5472.CAN-10-4117

King, H. O., Brend, T., Payne, H. L., Wright, A., Ward, T. A., Patel, K., ... Short, S. C. (2017). RAD51 Is a Selective DNA Repair Target to Radiosensitize Glioma Stem Cells. Stem Cell Reports, 8(1), 125-139. 
https://doi.org/10.1016/j.stemcr.2016.12.005

Kolenda, J., Jensen, S. S., Aaberg-Jessen, C., Christensen, K., Andersen, C., Brunner, N., \& Kristensen, B. W. (2011). Effects of hypoxia on expression of a panel of stem cell and chemoresistance markers in glioblastoma-derived spheroids. J Neurooncol, 103(1), 43-58. https://doi.org/10.1007/s11060-010-0357-8

Kong, D. S., Kim, M. H., Park, W. Y., Suh, Y. L., Lee, J. I., Park, K., ... Nam, D. H. (2008). The progression of gliomas is associated with cancer stem cell phenotype. Oncol Rep., 19(3), 639-643. https://doi.org/10.3892/or.19.3.639

Krogh, Petersen, J., Jensen, P., Dahl, Sorensen, M., \& Winther, Kristensen, B. (2016). Expression and Prognostic Value of Oct-4 in Astrocytic Brain Tumors. PLoS One, 11(12), e0169129. https://doi.org/10.1371/journal.pone.0169129

Laks, D. R., Masterman-Smith, M., Visnyei, K., Angenieux, B., Orozco, N. M., Foran, I., ... Kornblum, I. (2009). Neurosphere formation is an independent predictor of clinical outcome in malignant glioma. Stem Cells, 27(4), 980-987. https://doi.org/10.1002/stem.15

Lasky, J. L., Choe, M., \& Nakano, I. (2009). Cancer stem cells in pediatric brain tumors. Curr Stem Cell Res Ther, 4(4), 298-305. https://doi.org/10.2174/157488809789649278

Lavanya, C., Sibin, M. K., Srinivas, Bharath, M. M., Manoj, M. J., Venkataswamy, M. M., Bhat, D. I., ... Chetan, G. K. (2016). RNA interference mediated downregulation of human telomerase reverse transcriptase (hTERT) in LN18 cells. Cytotechnology, 68(6), 2311-2321. https://doi.org/10.1007/s10616-016-0025-8

Lee, H. K., Finniss, S., Cazacu, S., Bucris, E., Ziv-Av, A., Xiang, C., ... Brodie, C. (2013). Mesenchymal stem cells deliver synthetic microRNA mimics to glioma cells and glioma stem cells and inhibit their cell migration and self-renewal. Oncotarget, 4(2), 346-361. https://doi.org/10.18632/oncotarget.868

Lee, J., Kotliarova, S., Kotliarov, Y., Li, A., Su, Q., Donin, N. M., ... Fine, H. A. (2006). Tumor stem cells derived from glioblastomas cultured in bFGF and EGF more closely mirror the phenotype and genotype of primary tumors than do serum-cultured cell lines. Cancer Cell, 9(5), 391-403. https://doi.org/10.1016/j.ccr.2006.03.030

Lendahl, U., Zimmerman, L. B., \& McKay, R. D. (1990). CNS stem cells express a new class of intermediate filament protein. Cell, 60(4), 585-595. https://doi.org/10.1016/0092-8674(90)90662-X

Li, Z., Oganesyan, D., Mooney, R., Rong, X., Christensen, M. J., Shahmanyan, D., ... Gutova, M. (2016). L-MYC Expression Maintains Self-Renewal and Prolongs Multipotency of Primary Human Neural Stem Cells. Stem Cell Reports, 7(3), 483-495. https://doi.org/10.1016/j.stemcr.2016.07.013

Liau, L. M., Black, K. L., Martin, N. A., Sykes, S. N., Bronstein, J. M., Jouben-Steele, L., ... Cloughesy, T. F. (2000). Treatment of a patient by vaccination with autologous dendritic cells pulsed with allogeneic major histocompatibility complex class I-matched tumor peptides. Case Report. Neurosurg Focus, 9(6), e8. https://doi.org/090608

Liau, L. M., Prins, R. M., Kiertscher, S. M., Odesa, S. K., Kremen, T. J., Giovannone, A. J., .. Roth, M. D. (2005). Dendritic cell vaccination in glioblastoma patients induces systemic and intracranial T-cell responses modulated by the local central nervous system tumor microenvironment. Clin Cancer Res., 11(15), 5515-5525. https://doi.org/10.1158/1078-0432.CCR-05-0464

Lin, T. H., Kuo, H. C., Chou, F. P., \& Lu, F. J. (2008). Berberine enhances inhibition of glioma tumor cell migration and invasiveness mediated by arsenic trioxide. BMC Cancer, 8, 58.

https://doi.org/10.1186/1471-2407-8-58

Liu, G., Akasaki, Y., Khong, H. T., Wheeler, C. J., Das, A., Black, K. L., \& Yu, J. S. (2005). Cytotoxic T cell targeting of TRP-2 sensitizes human malignant glioma to chemotherapy. Oncogene, 24(33), 5226-5234. https://doi.org/10.1038/sj.onc.1208519

Liu, G., Khong, H. T., Wheeler, C. J., Yu, J. S., Black, K. L., \& Ying, H. (2003). Molecular and functional analysis of tyrosinase-related protein (TRP)-2 as a cytotoxic T lymphocyte target in patients with malignant glioma. J Immunother, 26(4), 301-312. https://doi.org/10.1097/00002371-200307000-00002

Lomonaco, S. L., Finniss, S., Xiang, C., Lee, H. K., Jiang, W., Lemke, N., ... Brodie, C. (2011). Cilengitide induces autophagy-mediated cell death in glioma cells. Neuro Oncol, 13(8), 857-865.

https://doi.org/10.1093/neuonc/nor073

Ma, H. I., Chiou, S. H., Hueng, D. Y., Tai, L. K., Huang, P. I., Kao, C. L., .. Sytwu, H. K. (2011). Celecoxib and 
radioresistant glioblastoma-derived CD133+ cells: improvement in radiotherapeutic effects. Laboratory investigation. J Neurosurg, 114(3), 651-662. https://doi.org/10.3171/2009.11.JNS091396

Marian, C. O., Cho, S. K., McEllin, B. M., Maher, E. A., Hatanpaa, K. J., Madden, C. J., ... Bachoo, R. M. (2010). The telomerase antagonist, imetelstat, efficiently targets glioblastoma tumor-initiating cells leading to decreased proliferation and tumor growth. Clin Cancer Res., 16(1), 154-163. https://doi.org/10.1158/1078-0432.CCR-09-2850

Marks, P. A., \& Dokmanovic, M. (2005). Histone deacetylase inhibitors: discovery and development as anticancer agents. Expert Opin Investig Drugs, 14(12), 1497-1511. https://doi.org/10.1517/13543784.14.12.1497

Massard, C., Deutsch, E., \& Soria, J. C. (2006). Tumour stem cell-targeted treatment: elimination or differentiation. Ann Oncol., 17(11), 1620-1624. https://doi.org/10.1093/annonc/mdl074

McCord, A. M., Jamal, M., Shankavaram, U. T., Lang, F. F., Camphausen, K., \& Tofilon, P. J. (2009). Physiologic oxygen concentration enhances the stem-like properties of CD133+ human glioblastoma cells in vitro. Mol Cancer Res., 7(4), 489-497. https://doi.org/10.1158/1541-7786.MCR-08-0360

Miao, H., Choi, B. D., Suryadevara, C. M., Sanchez-Perez, L., Yang, S., De Leon, G., ... Sampson, J. H. (2014). EGFRvIII-Specific Chimeric Antigen Receptor T Cells Migrate to and Kill Tumor Deposits Infiltrating the Brain Parenchyma in an Invasive Xenograft Model of Glioblastoma. PLoS ONE, 9(4), e94281. https://doi.org/10.1371/journal.pone.0094281

Michelakis, E. D., Sutendra, G., Dromparis, P., Webster, L., Haromy, A., Niven, E., ... Petruk, K. C. (2010). Metabolic modulation of glioblastoma with dichloroacetate. Sci Transl Med., 2(31), 31 ra34. https://doi.org/10.1126/scitranslmed.3000677

Moviglia, G. A., Carrizo, A. G., Varela, G., Gaeta, C. A., Paes, de Lima, A., Farina, P., \& Molina, H. (2008). Preliminary report on tumor stem cell/B cell hybridoma vaccine for recurrent glioblastoma multiforme. Hematol Oncol Stem Cell Ther, 1(1), 3-13. https://doi.org/10.1016/S1658-3876(08)50054-9

Mukherjee, B., McEllin, B., Camacho, C. V., Tomimatsu, N., Sirasanagandala, S., Nannepaga, S., ... Burma, S. (2009). EGFRvIII and DNA double-strand break repair: a molecular mechanism for radioresistance in glioblastoma. Cancer Res., 69(10), 4252-4259. https://doi.org/10.1158/0008-5472.can-08-4853

Ogden, A. T., Waziri, A. E., Lochhead, R. A., Fusco, D., Lopez, K., Ellis, J. A., ... Bruce, J. N. (2008). Identification of A2B5+CD133- tumor-initiating cells in adult human gliomas. Neurosurgery, 62(2), 505-514; discussion 514-505. https://doi.org/10.1227/01.neu.0000316019.28421.95

Ohtsu, N., Nakatani, Y., Yamashita, D., Ohue, S., Ohnishi, T., \& Kondo, T. (2016). Eva1 Maintains the Stem-like Character of Glioblastoma-Initiating Cells by Activating the Noncanonical NF-kappaB Signaling Pathway. Cancer Res., 76(1), 171-181. https://doi.org/10.1158/0008-5472.can-15-0884

Pallini, R., Ricci-Vitiani, L., Banna, G. L., Signore, M., Lombardi, D., Todaro, M., ... De Maria, R. (2008). Cancer stem cell analysis and clinical outcome in patients with glioblastoma multiforme. Clin Cancer Res., 14(24), 8205-8212. https://doi.org/10.1158/1078-0432.CCR-08-0644

Panchision, D. M., \& McKay, R. D. (2002). The control of neural stem cells by morphogenic signals. Curr Opin Genet Dev., 12(4), 478-487. https://doi.org/10.1016/S0959-437X(02)00329-5

Parajuli, P., Anand, R., Mandalaparty, C., Suryadevara, R., Sriranga, P. U., Michelhaugh, S. K., ... Mittal, S. (2016). Preferential expression of functional IL-17R in glioma stem cells: potential role in self-renewal. Oncotarget, 7(5), 6121-6135. https://doi.org/10.18632/oncotarget.6847

Pardal, R., Clarke, M. F., \& Morrison, S. J. (2003). Applying the principles of stem-cell biology to cancer. Nat Rev Cancer, 3(12), 895-902. https://doi.org/10.1038/nrc1232

Parney, I. F., Hao, C., \& Petruk, K. C. (2000). Glioma immunology and immunotherapy. Neurosurgery, 6(4), 778-791; discussion 791-772.

Pasqualini, R., \& Ruoslahti, E. (1996). Organ targeting in vivo using phage display peptide libraries. Nature, 380(6572), 364-366. https://doi.org/10.1038/380364a0

Piccirillo, S. G., Reynolds, B. A., Zanetti, N., Lamorte, G., Binda, E., Broggi, G., .. Vescovi, A. L. (2006). Bone morphogenetic proteins inhibit the tumorigenic potential of human brain tumour-initiating cells. Nature, 444(7120), 761-765. https://doi.org/10.1038/nature05349 
Pistollato, F., Abbadi, S., Rampazzo, E., Persano, L., Della, Puppa, A., Frasson, C., ... Basso, G. (2010). Intratumoral hypoxic gradient drives stem cells distribution and MGMT expression in glioblastoma. Stem Cells, 28(5), 851-862. https://doi.org/10.1002/stem.415

Pistollato, F., Rampazzo, E., Persano, L., Abbadi, S., Frasson, C., Denaro, L., ... Basso, G. (2010). Interaction of hypoxia-inducible factor-1alpha and Notch signaling regulates medulloblastoma precursor proliferation and fate. Stem Cells, 28(11), 1918-1929. https://doi.org/10.1002/stem.518

Porter, K. R., McCarthy, B. J., Freels, S., Kim, Y., \& Davis, F. G. (2010). Prevalence estimates for primary brain tumors in the United States by age, gender, behavior, and histology. Neuro Oncol., 12(6), 520-527. https://doi.org/10.1093/neuonc/nop066

Qatanani, M., \& Moore, D. D. (2005). CAR, the continuously advancing receptor, in drug metabolism and disease. Curr Drug Metab., 6(4), 329-339. https://doi.org/10.2174/1389200054633899

Rebetz, J., Tian, D., Persson, A., Widegren, B., Salford, L. G., Englund, E., ... Fan, X. (2008). Glial progenitor-like phenotype in low-grade glioma and enhanced CD133-expression and neuronal lineage differentiation potential in high-grade glioma. PLoS One, 3(4), e1936. https://doi.org/10.1371/journal.pone.0001936

Saito, K., Ohta, S., Kawakami, Y., Yoshida, K., \& Toda, M. (2017). Functional analysis of KIF20A, a potential immunotherapeutic target for glioma. J Neurooncol. https://doi.org/10.1007/s11060-016-2360-1

Sareddy, G. R., Nair, B. C., Gonugunta, V. K., Zhang, Q.-g., Brenner, A., Brann, D. W., ... Vadlamudi, R. K. (2012). Therapeutic significance of estrogen receptor $\beta$ agonists in gliomas. Molecular cancer therapeutics, 11(5), 1174-1182. https://doi.org/10.1158/1535-7163.MCT-11-0960

Sareddy, G. R., Viswanadhapalli, S., Surapaneni, P., Suzuki, T., Brenner, A., \& Vadlamudi, R. K. (2016). Novel KDM1A inhibitors induce differentiation and apoptosis of glioma stem cells via unfolded protein response pathway. Oncogene. https://doi.org/10.1038/onc.2016.395

Schittenhelm, J., Simon, P., Harter, P. N., Zachskorn, C., Schlaszus, H., Rottger, F., ... Mittelbronn, M. (2011). CD133 expression is associated with small round blue cell tumour morphology in human central nervous system neoplasms. Histopathology, 58(5), 739-749. https://doi.org/10.1111/j.1365-2559.2011.03801.x

Shay, J. W., \& Wright, W. E. (2002). Telomerase: a target for cancer therapeutics. Cancer Cell, 2(4), 257-265. https://doi.org/S1535610802001599

Sheng, X., Chen, H., Wang, H., Ding, Z., Xu, G., Zhang, J., ... Zhao, L. (2015). MicroRNA-130b promotes cell migration and invasion by targeting peroxisome proliferator-activated receptor gamma in human glioma. Biomed Pharmacother, 76, 121-126. https://doi.org/10.1016/j.biopha.2015.10.003

Silber, J., Lim, D. A., Petritsch, C., Persson, A. I., Maunakea, A. K., Yu, M., ... Hodgson, J. G. (2008). miR-124 and miR-137 inhibit proliferation of glioblastoma multiforme cells and induce differentiation of brain tumor stem cells. BMC Med., 6, 14. https://doi.org/10.1186/1741-7015-6-14

Simon, M., Hosen, I., Gousias, K., Rachakonda, S., Heidenreich, B., Gessi, M., ... Kumar, R. (2015). TERT promoter mutations: a novel independent prognostic factor in primary glioblastomas. Neuro Oncol., 17(1), 45-52. https://doi.org/10.1093/neuonc/nou158

Singh, M. M., Manton, C. A., Bhat, K. P., Tsai, W. W., Aldape, K., Barton, M. C., \& Chandra, J. (2011). Inhibition of LSD1 sensitizes glioblastoma cells to histone deacetylase inhibitors. Neuro Oncol., 13(8), 894-903. https://doi.org/10.1093/neuonc/nor049

Singh, S. K., Clarke, I. D., Terasaki, M., Bonn, V. E., Hawkins, C., Squire, J., \& Dirks, P. B. (2003). Identification of a cancer stem cell in human brain tumors. Cancer Res., 63(18), 5821-5828.

Skog, J., Edlund, K., Bergenheim, A. T., \& Wadell, G. (2007). Adenoviruses 16 and CV23 efficiently transduce human low-passage brain tumor and cancer stem cells. Mol Ther., 15(12), 2140-2145. https://doi.org/10.1038/sj.mt.6300315

Steponaitis, G., Kazlauskas, A., Skiriute, D., Valiulyte, I., Skauminas, K., Tamasauskas, A., \& Vaitkiene, P. (2016). Testin (TES) as a candidate tumour suppressor and prognostic marker in human astrocytoma. Oncol Lett, 12(5), 3305-3311. https://doi.org/10.3892/ol.2016.5077

Stupp, R., Mason, W. P., van den Bent, M. J., Weller, M., Fisher, B., Taphoorn, M. J., ... Mirimanoff, R. O. (2005). Radiotherapy plus concomitant and adjuvant temozolomide for glioblastoma. $N$ Engl J Med., 352(10), 987-996. https://doi.org/10.1056/NEJMoa043330 
Sullivan, J. P., Nahed, B. V., Madden, M. W., Oliveira, S. M., Springer, S., Bhere, D., ... Haber, D. A. (2014). Brain Tumor Cells in Circulation are Enriched for Mesenchymal Gene Expression. Cancer discovery, 4(11), 1299-1309. https://doi.org/10.1158/2159-8290.CD-14-0471

Sun, H., \& Zhang, S. (2011). Arsenic trioxide regulates the apoptosis of glioma cell and glioma stem cell via down-regulation of stem cell marker Sox2. Biochem Biophys Res Commun, 410(3), 692-697. https://doi.org/10.1016/j.bbrc.2011.06.060

Sun, P., Xia, S., Lal, B., Eberhart, C. G., Quinones-Hinojosa, A., Maciaczyk, J., ... Laterra, J. (2009). DNER, an epigenetically modulated gene, regulates glioblastoma-derived neurosphere cell differentiation and tumor propagation. Stem Cells, 27(7), 1473-1486. https://doi.org/10.1002/stem.89

Svensson, A., Ramos-Moreno, T., Eberstal, S., Scheding, S., \& Bengzon, J. (2016). Identification of two distinct mesenchymal stromal cell populations in human malignant glioma. J Neurooncol. https://doi.org/10.1007/s11060-016-2302-y

Takeuchi, H., Kondo, Y., Fujiwara, K., Kanzawa, T., Aoki, H., Mills, G. B., \& Kondo, S. (2005). Synergistic augmentation of rapamycin-induced autophagy in malignant glioma cells by phosphatidylinositol 3-kinase/protein kinase B inhibitors. Cancer Res., 65(8), 3336-3346. https://doi.org/10.1158/0008-5472.CAN-04-3640

Tamase, A., Muraguchi, T., Naka, K., Tanaka, S., Kinoshita, M., Hoshii, T., ... Hirao, A. (2009). Identification of tumor-initiating cells in a highly aggressive brain tumor using promoter activity of nucleostemin. Proceedings of the National Academy of Sciences of the United States of America, 106(40), 17163-17168. https://doi.org/10.1073/pnas.0905016106

Tenga, A., Beard, J. A., Takwi, A., Wang, Y. M., \& Chen, T. (2016). Regulation of Nuclear Receptor Nur77 by miR-124. PLoS One, 11(2), e0148433. https://doi.org/10.1371/journal.pone.0148433

Teplyuk, N. M., Mollenhauer, B., Gabriely, G., Giese, A., Kim, E., Smolsky, M., .. Krichevsky, A. M. (2012). MicroRNAs in cerebrospinal fluid identify glioblastoma and metastatic brain cancers and reflect disease activity. Neuro-Oncology, 14(6), 689-700. https://doi.org/10.1093/neuonc/nos074

Thirant, C., Bessette, B., Varlet, P., Puget, S., Cadusseau, J., Tavares, Sdos, R., ... Junier, M. P. (2011). Clinical relevance of tumor cells with stem-like properties in pediatric brain tumors. PLoS One, 6(1), e16375. https://doi.org/10.1371/journal.pone.0016375

Tominaga, N., Kosaka, N., Ono, M., Katsuda, T., Yoshioka, Y., Tamura, K., Lötvall, J., Nakagama, H., \& Ochiya, T. (2015). Brain metastatic cancer cells release microRNA-181c-containing extracellular vesicles capable of destructing blood-brain barrier. Nature Communications, 6, 6716. https://doi.org/10.1038/ncomms7716

Tomuleasa, C., Soritau, O., Kacso, G., Fischer-Fodor, E., Cocis, A., Ioani, H., ... Florian, I. S. (2010). Arsenic trioxide sensitizes cancer stem cells to chemoradiotherapy. A new approach in the treatment of inoperable glioblastoma multiforme. J BUON, 15(4), 758-762.

Tomuleasa, C., Soritau, O., Rus-Ciuca, D., Ioani, H., Susman, S., Petrescu, M., ... Florian, I. S. (2010). Functional and molecular characterization of glioblastoma multiforme-derived cancer stem cells. $J$ BUON, 15(3), 583-591.

U.S. National Institutes of Health. Cilengitide, Temozolomide, and Radiation Therapy in Treating Patients With Newly Diagnosed Glioblastoma and Methylated Gene Promoter Status (CENTRIC). Retrieved Apr., 17, 2012, from http://www.clinicaltrials.gov/ct2/show/NCT00689221

U.S. National Institutes of Health. Delta-24-RGD for Recurrent Malignant Gliomas. Retrieved Apr 17, 2012, from http://www.clinicaltrials.gov/ct2/show/NCT00805376.

U.S. National Institutes of Health. A Phase I Study of IMC-A12 in Combination With Temsirolimus in Pediatric Patients With Recurrent or Refractory Solid Tumors. Retrieved May 6, 2012, from http://www.clinicaltrials.gov/ct2/show/NCT01182883

U.S. National Institutes of Health. A Study of XL765 (SAR245409) in Combination With Temozolomide With and Without Radiation in Adults With Malignant Gliomas. Retrieved May 6, 2012, from http://www.clinicaltrials.gov/ct2/show/NCT00704080

U.S. National Institutes of Health. "Study to Assess Safety, Pharmacokinetics, and Efficacy of Oral CC-223 for Patients With Advanced Solid Tumors, Non-Hodgkin Lymphoma or Multiple Myeloma. Retrieved May 6, 2012, from http://www.clinicaltrials.gov/ct2/show/NCT01177397. 
U.S. National Institutes of Health. Tarceva/Rapamycin for Children With Low-grade Gliomas With or Without Neurofibromatosis Type 1 (NF1). Retrieved May 6, 2012, from http://www.clinicaltrials.gov/ct2/show/NCT00901849

U.S. National Institutes of Health. Vaccination With Dendritic Cells Loaded With Brain Tumor Stem Cells for Progressive Malignant Brain Tumor. Retrieved Apr 17, 2012, from http://www.clinicaltrials.gov/ct2/show/NCT01171469

Ulasov, I., Thaci, B., Sarvaiya, P., Yi, R., Guo, D., Auffinger, B., ... Lesniak, M. S. (2013). Inhibition of MMP14 potentiates the therapeutic effect of temozolomide and radiation in gliomas. Cancer Medicine, 2(4), 457-467. https://doi.org/10.1002/cam4.104

Ulasov, I. V., Nandi, S., Dey, M., Sonabend, A. M., \& Lesniak, M. S. (2011). Inhibition of Sonic hedgehog and Notch pathways enhances sensitivity of CD133(+) glioma stem cells to temozolomide therapy. Mol Med., 17(1-2), 103-112. https://doi.org/10.2119/molmed.2010.00062

Wakimoto, H., Kesari, S., Farrell, C. J., Curry, W. T., Zaupa, C., Aghi, M., ... Rabkin, S. D. (2009). Human glioblastoma-derived cancer stem cells: establishment of invasive glioma models and treatment with oncolytic herpes simplex virus vectors. Cancer Res., 69(8), 3472-3481. https://doi.org/10.1158/0008-5472.CAN-08-3886

Walton, J. D., Kattan, D. R., Thomas, S. K., Spengler, B. A., Guo, H.-F., Biedler, J. L., ... Ross, R. A. (2004). Characteristics of Stem Cells from Human Neuroblastoma Cell Lines and in Tumors. Neoplasia (New York, N.Y.), 6(6), 838-845. https://doi.org/10.1593/neo.04310

Wang, T., Xue, Y., Wang, M., \& Sun, Q. (2012). Silencing of the hTERT gene through RNA interference induces apoptosis via bax/bcl-2 in human glioma cells. Oncol Rep., 28(4), 1153-1158. https://doi.org/10.3892/or.2012.1952

Williams, R. F., Sims, T. L., Tracey, L., Myers, A. L., Ng, C. Y., Poppleton, H., ... Davidoff, A. M. (2010). Maturation of tumor vasculature by interferon-beta disrupts the vascular niche of glioma stem cells. Anticancer Res., 30(9), 3301-3308. https://doi.org/30/9/3301

Xu, Q., Liu, G., Yuan, X., Xu, M., Wang, H., Ji, J., .. Yu, J. S. (2009). Antigen-specific T-cell response from dendritic cell vaccination using cancer stem-like cell-associated antigens. Stem Cells, 27(8), 1734-1740. https://doi.org/10.1002/stem.102

Yalon, M., Rood, B., Macdonald, T. J., McCowage, G., Kane, R., Constantini, S., \& Packer, R. J. (2012). A feasibility and efficacy study of rapamycin and erlotinib for recurrent pediatric low-grade glioma (LGG). Pediatr Blood Cancer. https://doi.org/10.1002/pbc.24142

Yao, K. C., Komata, T., Kondo, Y., Kanzawa, T., Kondo, S., \& Germano, I. M. (2003). Molecular response of human glioblastoma multiforme cells to ionizing radiation: cell cycle arrest, modulation of the expression of cyclin-dependent kinase inhibitors, and autophagy. J Neurosurg, 98(2), 378-384. https://doi.org/10.3171/jns.2003.98.2.0378

Yao, Y., Wang, X., Jin, K., Zhu, J., Wang, Y., Xiong, S., ... Zhou, L. (2008). B7-H4 is preferentially expressed in non-dividing brain tumor cells and in a subset of brain tumor stem-like cells. J Neurooncol, 89(2), 121-129. https://doi.org/10.1007/s11060-008-9601-x

Yasumoto, Y., Miyazaki, H., Vaidyan, L. K., Kagawa, Y., Ebrahimi, M., Yamamoto, Y., ... Owada, Y. (2016). Inhibition of Fatty Acid Synthase Decreases Expression of Stemness Markers in Glioma Stem Cells. PLoS One, 11(1), e0147717. https://doi.org/10.1371/journal.pone.0147717

Ylivinkka, I., Sihto, H., Tynninen, O., Hu, Y., Laakso, A., Kivisaari, R., ... Hyytiainen, M. (2017). Motility of glioblastoma cells is driven by netrin-1 induced gain of stemness. J Exp Clin Cancer Res., 36(1), 9. https://doi.org/10.1186/s13046-016-0482-0

Yu, L., Baxter, P. A., Zhao, X., Liu, Z., Wadhwa, L., Zhang, Y., ... Li, X. N. (2011). A single intravenous injection of oncolytic picornavirus SVV-001 eliminates medulloblastomas in primary tumor-based orthotopic xenograft mouse models. Neuro Oncol., 13(1), 14-27. https://doi.org/10.1093/neuonc/noq148.

Yu, L., Zhong, Z., Sun, H., Yan, L., He, B., Li, S., ... Huang, Y. (2016). Effect of pterostilbene on glioma cells and related mechanisms. Am J Transl Res., 8(12), 5211-5218.

Zemp, F. J., Lun, X., McKenzie, B. A., Zhou, H., Maxwell, L., Sun, B., ... Forsyth, P. A. (2013). Treating brain tumor-initiating cells using a combination of myxoma virus and rapamycin. Neuro-Oncology, 15(7), 
904-920. https://doi.org/10.1093/neuonc/not035.

Zhen, Y., Zhao, S., Li, Q., Li, Y., \& Kawamoto, K. (2010). Arsenic trioxide-mediated Notch pathway inhibition depletes the cancer stem-like cell population in gliomas. Cancer Lett, 292(1), 64-72.

https://doi.org/10.1016/j.canlet.2009.11.005

Zhong, X., Liu, X., Li, Y., Cheng, M., Wang, W., Tian, K., ... Zhou, Y. (2016). HMGA2 sustains self-renewal and invasiveness of glioma-initiating cells. Oncotarget, 7(28), 44365-44380. https://doi.org/10.18632/oncotarget.9744

Zhu, C., Kros, J. M., van der Weiden, M., Zheng, P., Cheng, C., \& Mustafa, D. A. (2017). Expression site of P2RY12 in residential microglial cells in astrocytomas correlates with M1 and M2 marker expression and tumor grade. Acta Neuropathol Commun, 5(1), 4. https://doi.org/10.1186/s40478-016-0405-5.

Zhu, D., Tu, M., Zeng, B., Cai, L., Zheng, W., Su, Z., \& Yu, Z. (2017). Up-regulation of miR-497 confers resistance to temozolomide in human glioma cells by targeting mTOR/Bcl-2. Cancer Med., https://doi.org/10.1002/cam4.987

Zhuang, W., Li, B., Long, L., Chen, L., Huang, Q., \& Liang, Z. (2011). Induction of autophagy promotes differentiation of glioma-initiating cells and their radiosensitivity. Int J Cancer, 129(11), 2720-2731. https://doi.org/10.1002/ijc.25975

\section{Copyrights}

Copyright for this article is retained by the author(s), with first publication rights granted to the journal.

This is an open-access article distributed under the terms and conditions of the Creative Commons Attribution license (http://creativecommons.org/licenses/by/4.0/). 